\title{
Implementation of Group Counseling and Role- Playing: The Investigation of Students Social Interaction Improvement
}

\author{
Subandi Subandi ${ }^{1 *}$, Ida Faridatul Hasanah ${ }^{1}$, Laila Ludfiana Dewi ${ }^{1}$, \\ Siti Roudlotul Jannah ${ }^{2}$ \\ Universitas Islam Negeri Raden Intan Lampung, Indonesia ${ }^{1}$ \\ Institut Agama Islam Ma'arif NU (IAIMNU) Metro Lampung, Indonesia² \\ Qsubandi@radenintan.ac.id*
}

\section{Article Information:}

Received October 28, 2019

Revised November 20, 2019

Accepted December 3, 2019

Keywords: group counseling, role-playing techniques, students social interaction

\begin{abstract}
The authors found many students with low social interaction at school and lack of methods in anticipating this problem. This article contributes to providing alternative methods for enhancing students' social interaction by using role-playing techniques in group counseling. The purpose of this study is to determine the effectiveness of the role-playing technique in improving the social interaction of 8th-grade students at Public Junior High School 7 Bandar Lampung. The authors use social interaction scales to collect data and quasi-experimental research design methods. The subjects of the study were 16 students of 8th-grade Public Junior High School 7 Bandar Lampung which selected by purposive sampling. Data analysed using Wilcoxon Test. The results of the study concluded that $z=-2.524$ and $p<0.05$. This means that group counseling services with role-playing techniques are effective to improve social interaction for 8th-grade students at Public Junior High School 7 Bandar Lampung.
\end{abstract}

\section{INTRODUCTION}

Interaction is a basic need for humans because they are social beings who will always be in contact with other people, nature, and other creatures. In the process of social interaction, self-adjustment is one of the activities that could not be avoided. The adjustment term related to a variety of unique ways shown by someone to be able to interact with others (Dufner et al., 2019). Social interaction is a process related to the overall behavior of group members to others (Kafetsios et al., 2018; Nezlek et al., 2008). The relationship between individuals and groups that can influence, change or improve the behavior of other individuals and vice versa, it includes social interactions according to (Zimmerman \& Bonner, 1996) formula.

Adolescence is a period of chaos and a time when someone faces many problems, challenges, and conflicts in the search for identity (Elliott et al., 2017). This period is a transition from childhood to adulthood, a period when someone who departs to seek identity becomes an adult (Elliott et al., 2017; Houltberg et al., 2016). They tend to spend more time with peer groups rather than being at home, and if social interactions are positive, it will undoubtedly be beneficial for adolescent development (Tompsett et al., 2016).

Based on results of (Widhianto \& Sugiyo, 2015) study, seventh grade of public junior high school 1 Buayan showed a lack of social interaction with peers as indicated by the lack of willingness to cooperate with friends, the existence of unsportsmanlike competition, fellow

How to cite:

E-ISSN:

Published by:
Subandi, S., Hasanah, I., Dewi, L., \& Jannah, S. (2020). Implementation of Group Counseling and RolePlaying: The Investigation of Students Social Interaction Improvement. Islamic Guidance and Counseling Journal, 3(1). https://doi.org/10.25217/igcj.v3i1.613 2614-1566

Institut Agama Islam Ma'arif NU (IAIMNU) Metro Lampung 
friends due to the selfishness of each students, they are also difficult to adjust to the school environment, mainly associating with peers and some students have not been able to reduce the conflicts with their friends. This also happened to Demak Public High School 1. Based on Normanita et al. (2018) study, can be seen there are students who have not been able to interact socially well with their peers, this is also supported by the presence of some students who are less open when communicating with friends or with others, lacking the courage to express opinions, students are often confused and embarrassed when dealing with people. Some students are active in their opinions but not in discussion forums. While the phenomenon that occurs in Bandar Lampung junior high School 7, many students have low social interaction. Based on the results of interviews obtained from school counselors, students, particularly students of eighth grade, some students show a moody, aloof, indifferent to the surrounding environment and do not pay attention to subjects when the teacher explains.

By given the importance of social interaction in social life, especially when adolescence is the right time to instill and increase social awareness. Therefore, an effective solution is needed. When students try to solve the problems they face, counseling can be considered as the core of the process of providing essential help (Corey, 2013). Curative assistance efforts and develop to the personal ability in solving problems in groups or together directed by the counselor, which called by group counseling. The principle of group counseling is to encourage by utilizing the potential that is owned and facilitate the growth and development to make positive changes in individuals (Corey, 2013; DeLucia-Waack et al., 2013; Shulman, 2010). Some of the problems discussed during the group counseling process include the ability of a person to build communication relationships, the development of self-esteem, and skills in overcoming obstacles (Chen \& Rybak, 2017; Ratts et al., 2016; Shapiro et al., 2018).

The dramatization of some problems that can arise in relationships with others, for instance, conflicts that occur in someone in social relationships, this technique is called the role-playing (Corsini, 2017). In this technique, some people hold a specific role and play a social interaction scene that contains a problem that must be solved. With this technique, students play particular roles and who play it is human behavior in social relations (Osborn \& Costas, 2013).

Several reseaches have found that role-playing is an effective approach to improve counseling skills for counselor (Osborn \& Costas, 2013), social skills (Gaffney \& McFall, 1981), law enforcement and negotiation skills (Van Hasselt et al., 2008). Unfortunately, nonte of mentioned reseaches focused on social interaction variable. Therefore, role-playing techniques in group counseling is essential to investigate. In particular, to increase the social interaction of students. Related to the description above, then an experimental research effort is carried out to determine the effectiveness of role-playing techniques in group counseling to improve social interaction. This study aims to determine the effectiveness of counseling group services with role-playing techniques in increasing student social interaction.

\section{METHODS}

This research is a Quasi-experiment pretest-potstest control group design. The sample in this research were 16 students of Public Junior High School 7 Bandar Lampung, selected by using purposive sampling technique. The selected sample is students who have low levels of social interaction. From this sample, the researcher divided the experimental group and the control group by two experimental groups and two control groups, respectively. The experimental group is the group that will be given the intervention of group counseling with role-playing techniques while the control group is the group that is given conventional group guidance services. In this study, authors used social interaction scale. Social interaction scale 
reliability $\alpha=0.902$ and validity, based on item total correlations ranged from $0.329-0.822$. The higher the score, the higher students' social interaction.

The procedure in this study by giving experiment group a pretest to measure the behavior scores of students who have low social interaction using a questionnaire. Once it is known that students who have low social interaction behavior, then given group counseling services with role-playing techniques, then it given a posttest to measure the scores of students' social interaction behavior after being treated by group counseling services with role-playing techniques. The next step is comparing the results of pretest and posttest to find out whether group counseling services using role-playing techniques are able to help students reduce low social interaction behavior by comparing the pre-test score with the post-test score. Data is processed and analyzed using Wilcoxon test.

\section{RESULTS AND DISCUSSION}

The findings in this study both control and experiment group are effective to improve students' social interaction. Based on the statistical analysis on the Table 1. The experiment group showed a highly significant mean improvement from pretest (37.87) to posttest (74.12). It is also in line with the probability $(\mathrm{p}=0.012<0.05)$, which mean there is a statistically significant differences between before and after participants treated with role-playing technique within group counseling. In the other side, the control group showed not a significant mean improvement from pretest (65.12) to posttest (68.25). But this result is also in line with the probability $(\mathrm{p}=0.017<0.05)$, which mean there is a statistically significant differences between before and after participants treated with conventional counseling services. Although, both group are statistically significant to improve students' social interaction but the experiment $(\mathrm{p}=0.012<0.05)$ showed a higher score of probability than control $(0.017<0.05)$ group.

\begin{tabular}{llcccccc}
\hline \multirow{2}{*}{ Variable } & \multirow{2}{*}{ Group } & \multicolumn{2}{c}{ Pretest } & \multicolumn{2}{c}{ Posttest } & \multirow{2}{*}{$\mathrm{z}$} & \multirow{2}{*}{$\mathrm{P}$} \\
\cline { 3 - 6 } & & $\mathrm{M}$ & $\mathrm{SD}$ & $\mathrm{M}$ & $\mathrm{SD}$ & & \\
\hline Social Interaction & Experiment & 37.87 & 5.13 & 74.12 & 1.72 & -2.524 & 0.012 \\
& Control & 65.12 & 4.25 & 68.25 & 2.18 & -2.384 & 0.017 \\
\hline
\end{tabular}

Table 1 . The result of impact analysis

The findings in this study showed that both groups, experiment and control, are effective to improve social interaction but the higher impact seen on the experiment group. The authors believe the impact differences are more likely affected by the role-playing technique. The authors have expected these findings.

Somewhat surprisingly, despite the effectiveness of the intervention, the authors did not expect that control group intervention would be almost as significant as the experiment group intervention. There was no evidence of other variables that influence social interaction of students in the control group. Nonetheless, there was a pronounced unseen variable like counselor skills in leading and directing the dynamic interactions between counselees within the group. Research suggests that with the dynamics of the counseling will encourage the counselee to speak up and interact with others within the group (Chen \& Rybak, 2017; Corey, 2013; Shapiro et al., 2018; Shulman, 2010).

The authors have expected the role-playing impact on the social interaction. Research suggests that role-playing is the most preferred learning method to improve communication skills (Jin et al., 2019; Lilja et al., 2000) and preparation before doing social work (Fulton et al., 2019). The literature emphasises the urgency of conducting role-playing in a controlled and supportive environment (Fulton et al., 2019; Stobbs, 2015). The safe and controlled environment by the counselor supports the improvement of social interaction, where the 
counselee didn't feel intimidated to speak their opinion in the decided character. In the other hand, role-playing also useful to improve mental health (Hubbard, 2014).

Despite the insight findings in this study, the are several limitations that can be found. First, this study focused on social interaction only and didn't show how other variables that probably would be affecting the final result of students' social interaction. Second, this study conducted in a limited sample, only in one school with 16 students invited to the study. Therefore, the future study needed to add several variables that empirically proven related to the social interaction and fully controlled the intervention and the environment (i.e. counselor should and shouldn't do in the counseling process, cultural aspects, etc.). Lastly, future research need to consider using more participant in group counseling.

\section{CONCLUSIONS}

Although both interventions, the role-playing within group counseling and group counseling without any specific technique, is effective to improve students' social interaction but the experiment group showed a higher significant impact on the social interaction. Unfortunately, this study has some limitations. Therefore, future study should add several variables that empirically proven related to social interaction and fully controlled the environment while conducting the intervention.

\section{ACKNOWLEDGMENTS}

The author expresses their sincere appreciations to the Rector of Universitas Islam Negeri Raden Intan, Prof. Dr. Mukri, M.Ag., and the Dean of Tarbiyah faculty, Prof. Dr. Nirva Diana, M.Pd., for their support. The acknowledgment also extended to everyone who contributed to this study.

\section{AUTHOR CONTRIBUTION STATEMENTS}

SB and IFH designed the research proposal and the instrument. LLD and SRJ collected the data. SB, IFH, LLD and SRJ conducted the experiment together. SRJ designed and performed the analysis. All the author wrote the manuscript together and agree with the final version of the manuscript. There is no conflict of interest.

\section{REFERENCES}

Chen, M., \& Rybak, C. (2017). Group Leadership Skills: Interpersonal Process in Group Counseling and Therapy. SAGE Publications. Retrieved from Google Scholar

Corey, G. (2013). Theory and practice of counseling and psychotherapy. Cengage Learning. Retrieved from Google Scholar

Corsini, R. (2017). Role playing in psychotherapy. Routledge. Retrieved from Google Scholar

DeLucia-Waack, J. L., Kalodner, C. R., \& Riva, M. (2013). Handbook of Group Counseling and Psychotherapy. SAGE Publications. Retrieved from Google Scholar

Dufner, M., Gebauer, J. E., Sedikides, C., \& Denissen, J. J. A. (2019). Self-Enhancement and Psychological Adjustment: A Meta-Analytic Review. Personality and Social Psychology Review, 23(1), 48-72. https://doi.org/10.1177/1088868318756467

Elliott, M. C., Shuey, E. A., Zaika, N., Mims, L., \& Leventhal, T. (2017). Finding Home: A Qualitative Approach to Understanding Adolescent Mothers' Housing Instability. American Journal of Community Psychology, 60(1-2), 55-65. https://doi.org/10.1002/ajcp.12112

Fulton, A. E., Dimitropoulos, G., Ayala, J., McLaughlin, A. M., Baynton, M., Blaug, C., Collins, T., Elliott, G., Judge-Stasiak, A., Letkemann, L., \& Ragan, E. (2019). RolePlaying: A Strategy for Practicum Preparation for Foundation Year MSW Students. 
Implementation of Group Counseling and Role-Playing: The Investigation of Students Social Interaction Improvement

Journal of Teaching in Social Work, 39(2), 163-180. https://doi.org/10.1080/08841233.2019.1576573

Gaffney, L. R., \& McFall, R. M. (1981). A comparison of social skills in delinquent and nondelinquent adolescent girls using a behavioral role-playing inventory. Journal of Consulting and Clinical Psychology, 49(6), 959-967. https://doi.org/10.1037/0022006X.49.6.959

Houltberg, B. J., Sheffield Morris, A., Cui, L., Henry, C. S., \& Criss, M. M. (2016). The Role of Youth Anger in Explaining Links Between Parenting and Early Adolescent Prosocial and Antisocial Behavior. The Journal of Early Adolescence, 36(3), 297-318. https://doi.org/10.1177/0272431614562834

Hubbard, G. B. (2014). Customized Role Play: Strategy for Development of Psychiatric Mental Health Nurse Practitioner Competencies. Perspectives in Psychiatric Care, 50(2), 132-138. https://doi.org/10.1111/ppc.12031

Jin, H. K., Park, S. H., Kang, J. E., Choi, K. S., Kim, H. Ah., Jeon, M. S., \& Rhie, S. J. (2019). The influence of a patient counseling training session on pharmacy students' self-perceived communication skills, confidence levels, and attitudes about communication skills training. BMC Medical Education, 19(1), 172. https://doi.org/10.1186/s12909-019-1607-X

Kafetsios, K., Hess, U., \& Nezlek, J. B. (2018). Self-construal, affective valence of the encounter, and quality of social interactions: Within and cross-culture examination. The $\begin{array}{llll}\text { Journal of Social } & \text { Psychology, }\end{array}$ https://doi.org/10.1080/00224545.2017.1305326

Lilja, J., Larsson, S., Hamilton, D., \& Issakainen, J. (2000). Empathy as a communication strategy in the pharmacy-A study based on cognitive and behavioural analysis. International Journal of Pharmacy Practice, 8(3), 176-187. https://doi.org/10.1111/j.2042-7174.2000.tb01003.x

Nezlek, J. B., Kafetsios, K., \& Smith, C. V. (2008). Emotions in Everyday Social Encounters: Correspondence Between Culture and Self-Construal. Journal of Cross-Cultural Psychology. https://doi.org/10.1177/0022022108318114

Normanita, R. W., Kurniawan, K., \& Nusantoro, E. (2018). Meningkatkan Interaksi Sosial dengan Teman Sebaya Melalui Layanan Bimbingan Kelompok dengan Teknik Cinematherapy. Indonesian Journal of Guidance and Counseling: Theory and Application, 7(3), 1-7. Retrieved from Google Scholar

Osborn, D., \& Costas, L. (2013). Role-Playing in Counselor Student Development. Journal of Creativity in Mental Health, 8(1), 92-103. https://doi.org/10.1080/15401383.2013.763689

Ratts, M. J., Singh, A. A., Nassar-McMillan, S., Butler, S. K., \& McCullough, J. R. (2016). Multicultural and Social Justice Counseling Competencies: Guidelines for the Counseling Profession. Journal of Multicultural Counseling and Development, 44(1), 28-48. https://doi.org/10.1002/jmcd.12035

Shapiro, J., Peltz, L., \& Bernadett-Shapiro, S. (2018). Basics of Group Counseling and Psychotherapy: An Introductory Guide. Faculty Book Gallery. Retrieved from Google Scholar

Shulman, L. (2010). Dynamics and Skills of Group Counseling. Cengage Learning. Retrieved from Google Scholar

Stobbs, N. (2015). Role-play without humiliation: Is it possible? The Clinical Teacher, 12(2), 128-130. https://doi.org/10.1111/tct.12295

Tompsett, C. J., Veits, G. M., \& Amrhein, K. E. (2016). Peer Delinquency and Where Adolescents Spend Time with Peers: Mediation and Moderation of Home 
Neighborhood Effects on Self-Reported Delinquency. Journal of Community Psychology, 44(2), 263-270. https://doi.org/10.1002/jcop.21759

Van Hasselt, V. B., Romano, S. J., \& Vecchi, G. M. (2008). Role Playing: Applications in Hostage and Crisis Negotiation Skills Training. Behavior Modification, 32(2), 248-263. https://doi.org/10.1177/0145445507308281

Widhianto, W., \& Sugiyo, S. (2015). Pengaruh Bimbingan Kelompok Teknik Sosiodrama Terhadap Interaksi Sosial dengan Teman Sebaya. Indonesian Journal of Guidance and Counseling: Theory and Application, 4(4). Retrieved from Google Scholar Zimmerman, B. J., \& Bonner, S. (1996). A social cognitive view of strategic learning. Strategic Learning: Skill, Will and Self-Regulation. Hillsdale, NJ: Erlbaum. Retrieved from Google Scholar

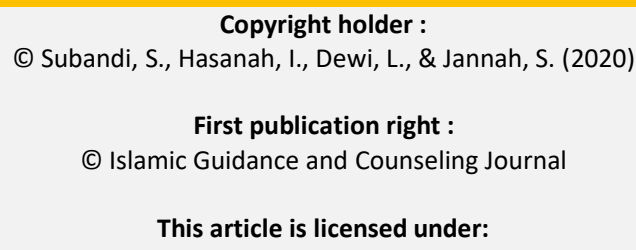

\section{CC-BY-SA}

